\title{
Improvement of entrepreneurship skills in building renovation technique
}

\author{
Devin Defriza Harisdani ${ }^{1 *}$, Dwi Lindarto Hadinugroho ${ }^{1}$, Andy Putra Rambe ${ }^{2}$ \\ ${ }^{1}$ Department of Architecture, Faculty of Engineering, Universitas Sumatera Utara, Medan - \\ Indonesia \\ ${ }^{2}$ Department of Civil Engineering, Faculty of Engineering, Universitas Sumatera Utara, \\ Medan - Indonesia \\ *Email: devin.defriza@usu.ac.id
}

\begin{abstract}
Increasing the number of routine worship activities and the reduced quality of worship facilities services forced the Al Jihad Mosque, Siti Rejo II Village, Medan Amplas District and surrounding communities to carry out renovation of development in a self-managed / independent manner. In the implementation of the initial stages of the renovation there was a problem of the lack of knowledge and skills of human and community resources regarding building renovation techniques. To be the solution to the problem mentioned above, together with the Universitas Sumatera Utara (USU) TALENTA 2019 Community Service Team, the mosque management as the responsible and stakeholders in improving the quality of community human resources in its organization will carry out activities of understanding building drawings, controlling building costs and simulating stone and wood construction in a micro practice in building renovations. Activities to improve the quality of the community through this knowledge and skills will develop the characteristics of community entrepreneurship in the field of building renovation services or techniques.
\end{abstract}

Keywords: Building Renovation Techniques, Entrepreneurship, Al Jihad II Mosque Amplas

\begin{abstract}
Abstrak
Peningkatan jumlah kegiatan ibadah rutin dan berkurangnya mutu layanan sarana ibadah memaksa pihak Masjid Al Jihad, Kelurahan Siti Rejo II, Kecamatan Medan Amplas dan masyarakat sekitar untuk melakukan renovasi pembangunan secara swakelola/mandiri. Dalam pelaksanaan tahapan awal renovasi tersebut terdapat masalah rendahnya pengetahuan dan keterampilan sumber daya manuasia dan masyarakat tentang teknik renovasi bangunan. Menjadi solusi permasalahan tersebut diatas, bersama Tim Pengabdian Masayarakat (Abdimas) Universitas Sumatera Utara TALENTA 2019, pihak manajemen Masjid sebagai penanggungjawab dan stakeholders dalam peningkatan kualitas SDM masyarakat dalam organisasinya akan melakukan kegiatan pemahaman gambar, kontrol biaya bangunan serta simulasi konstruksi batu dan kayu dalam sebuah praktek mikro dalam renovasi bangunan. Kegiatan peningkatan kualitas masyarakat melalui pengetahuan dan keterampilan ini akan mengembangkan karakteristik kewirausahaan masyarakat dibidang jasa atau teknik renovasi bangunan.
\end{abstract}

Kata Kunci: Teknik Renovasi Bangunan, Kewirausahaan, Masjid Al Jihad II Amplas

\section{PENDAhUluAN}

\subsection{Analisis Situasi}

Masyarakat dalam lingkungan Kelurahan adalah SDM dalam manajemen pengelolaan masjid melalui Badan Kemakmuran Mesjid (BKM). Pada Masjid Al Jihad, Siti Rejo II Medan Amplas, peningkatan jumlah kegiatan ibadah rutin berjamaah dan berkurangnya mutu layanan sarana ibadah memaksa pihak BKM Masjid dan masyarakat sekitar untuk melakukan renovasi pembangunan secara swakelola/mandiri dalam mengantisipasi masalah kegiatan ibadah islami. 
Masyarakat sekitar sangat mengenal rumah ibadah ini sebagai identitas penting dalam perkembangan wilayah J1. Pembangunan kawasan STM, Medan (Gambar 1). Kegiatan ibadah rutin seperti sholat lima waktu berjamaah makin meningkat disamping kegiatan perwiridan dan pengajian sore yang rutin dilakukan oleh Badan Kemakmuran Masjid (BKM) dengan peminat yang menggembirakan terutama dihadiri oleh ibu ibu pengajian dan anak-anak dalam forum pengajian maghrib yang ramai. BKM Masjid beserta masyarakat akan melakukan peningkatan mutu layanan di masjid ini dengan melakukan renovasi pembangunan untuk mengakomodasi kegiatan ibadah islami.

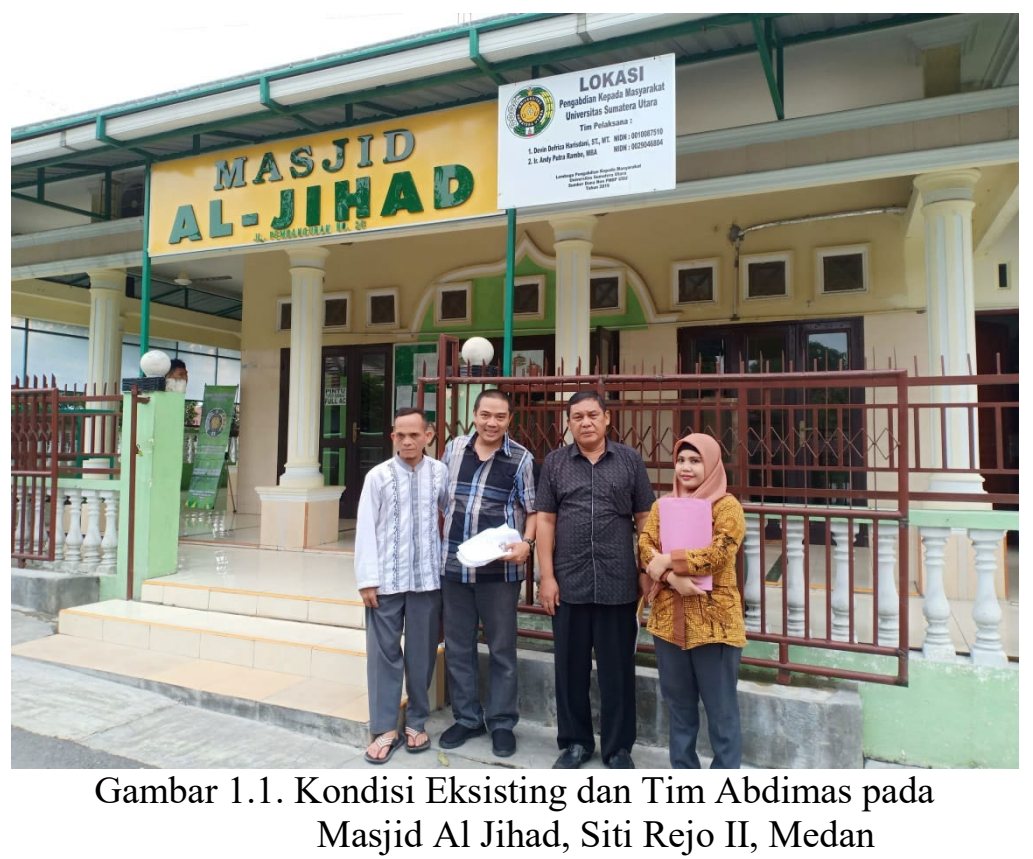

Masjid sebagai salah satu fasilitas umum publik yang memiliki kebutuhan bentang bangunan lebar dan luas, sehingga dalam renovasinya perlu kajian dan pemahaman yang baik oleh orang yang ahli yang berpengalaman dan memiliki latar belakang pengetahuan konstruksi yang memadai. Namun, ketika renovasi dilakukan secara swakelola/mandiri tanpa didampingi ahlinya, maka muncul banyak pertanyaan dalam pelaksanaan renovasinya di lapangan, tentang gambar desain renovasi, biaya pembangunan serta konstruksi bangunan. Sehingga dalam renovasi masjid swakelola/mandiri terkadang dibutuhkan waktu cukup lama karena terkendala masalah teknis (selain aspek biaya tentunya). Bahkan ada beberapa renovasi bangunan masjid akhirnya terhenti pelaksanaannya di tengah jalan karena kurang memperhitungkan masalah-masalah yang berkaitan dengan arsitektur, struktur, atau faktor perencanaan anggarannya.

\subsection{Permasalahan Mitra}

Sejalan dengan renovasi pembangunan yang akan dilakukan, pihak BKM Masjid sebagai penanggungjawab adalah juga sebagai stakeholders dalam pengembangan kualitas SDM masyarakat dalam organisasinya. Penugasan kepada anggota BKM akan dilakukan sebagai pengawas pelaksaanaan pekerjaan renovasi tersebut. Masalah yang dihadapi sekarang adalah rendahnya pengetahuan dan keterampilan para anggota BKM dalam teknis renovasi bangunan serta diperlukan pula pengembangan kewirausahaan masyarakat yang mampu digunakan sebagai upaya peningkatan keberhasilan dan kelancaran renovasi ini.

Dalam beberapa literatur maupun artikel kewirausahaan banyak dikemukakan nilai nilai yang terkandung dalam jiwa kewirausahaan (Zimmerer, 2008; Arief, 2006), antara lain kreatif dan inovatif, mampu melihat dan memanfaatkan peluang, mampu bekerjasama, memiliki motivasi 
yang tinggi, kerja keras, berani menghadapi risiko, percaya diri yang tinggi, berorientasi pada tugas dan hasil, memiliki jiwa pemimpin, optimis, memiliki komitmen dan proaktif menjadi nilai dan materi yang di-transfer-kan pada Abdimas ini.

Namun tidak semua aspek kewirausahaan dapat diajarkan dengan perspektif pembelajaran yang sama menurut Albornoz (2008) dan Kellet (2006). Alasan inilah yang memperkuat pentingnya model experiential learning (pengalaman langsung) sebagai praktek langsung atau simulasi dalam pembelajaran kewirausahaan dengan cara praktek langsung atau belajar memecahkan permasalahan atas rendahnya pengetahuan dan keterampilan SDM BKM dan masyarakat tentang teknik renovasi bangunan dalam renovasi pembangunan masjid Al Jihad ini.

\section{METODE PELAKSANAAN}

Metode pelaksanaan dari Abdimas ini adalah kegiatan pelatihan dan simulasi yang dilaksanakan bersama mitra. Setelah mendapat persetujuan dari pihak mitra, BKM Masjid Al Jihad, Siti Rejo II, Medan dan penandatanganan surat pernyataan kesediaan bekerjasama, maka pelaksanaan pengabdian dilakukan setelah penandatanganan kontrak Abdimas antara Ketua Pelaksana Pengabdian dengan Ketua Lembaga Pengabdian Masyarakat USU dengan metoda berupa pembelajaran experiental learning (Kolb, 1999). Model ini menekankan pada sebuah model pembelajaran yang holistik dalam proses belajar dimana pengalaman mempunyai peran sentral dalam proses belajar. Istilah "experiential" di sini untuk membedakan antara teori belajar kognitif yang cenderung menekankan kognisi lebih daripada afektif. Experiential learning dapat didefinisikan sebagai tindakan untuk mencapai sesuatu berdasarkan pengalaman guna meningkatkan keefektifan dari hasil belajar itu sendiri.

\section{HASIL DAN PEMBAHASAN}

Dalam Abdimas ini dipersiapkan materi dalam meningkatkan teknik renovasi bangunan masjid, diharapkan para masyarakat yang berpartisipasi dalam pelaksanaan renovasi bangunan masjid ini dapat lebih terampil dan bertanggungjawab, mengingat dampak selanjutnya yang mungkin terjadi adalah kegagalan bangunan karena adanya kesalahan dalan desain renovasi dan pelaksanaan teknik konstruksinya. Untuk ini dilakukan pelatihan pemahaman terhadap gambar kerja pembangunan.

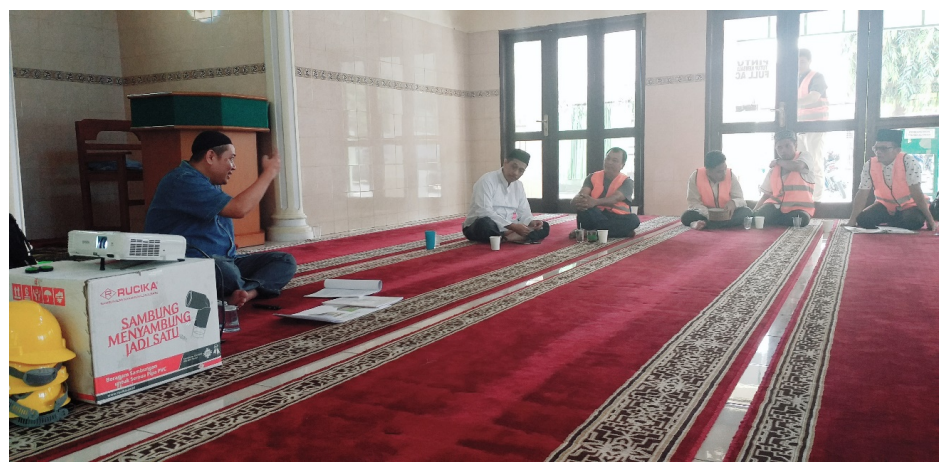

Gambar 3.1. Pelatihan pemahaman terhadap gambar kerja pembangunan 


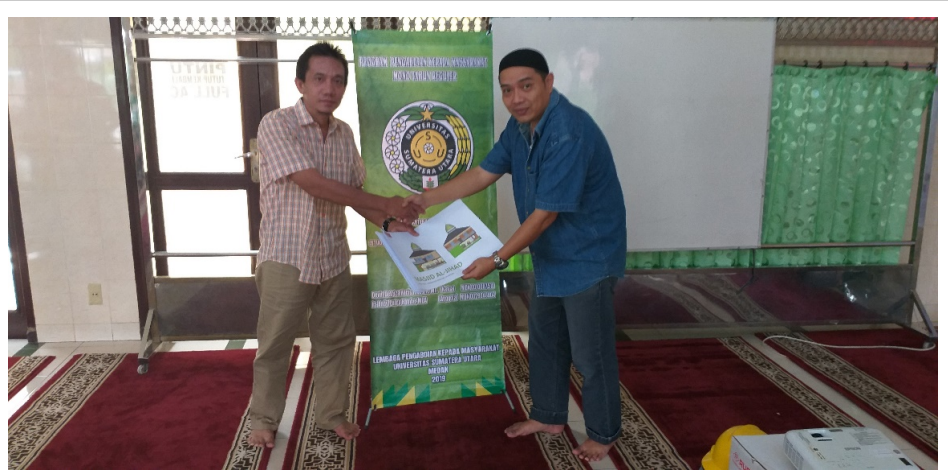

Gambar 3.2. Penyerahan materi gambar renovasi bangunan masjid

Peningkatan keterampilan merupakan nilai tambah bagi masyarakat dan dapat membuka peluang berwirausaha bagi mereka untuk memperoleh pekerjaan dibidang teknis bangunan lainnya. Masyarakat pengguna masjid akan merasa nyaman dan aman dalam menggunakan fasilitas layanan publik di lingkungan permukimannya karena mereka tahu bahwa fasilitas tersebut dilaksanakan dengan pemahaman dan pelaksanaan konstruksi sesuai standar bangunan yang berlaku. Dilakukan pula pelatihan kontrol biaya dan keteranpilan renovasi bangunan serta penyerahan peralatan simulasi terkait dalam Abdimas ini.

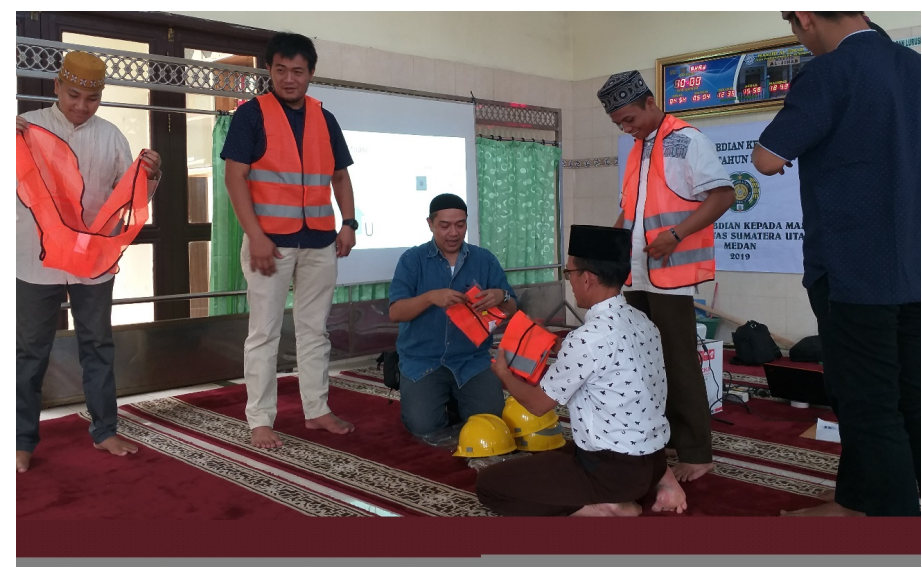

Gambar 3.3. Pelatihan keteranpilan renovasi bangunan dan peralatan terkait

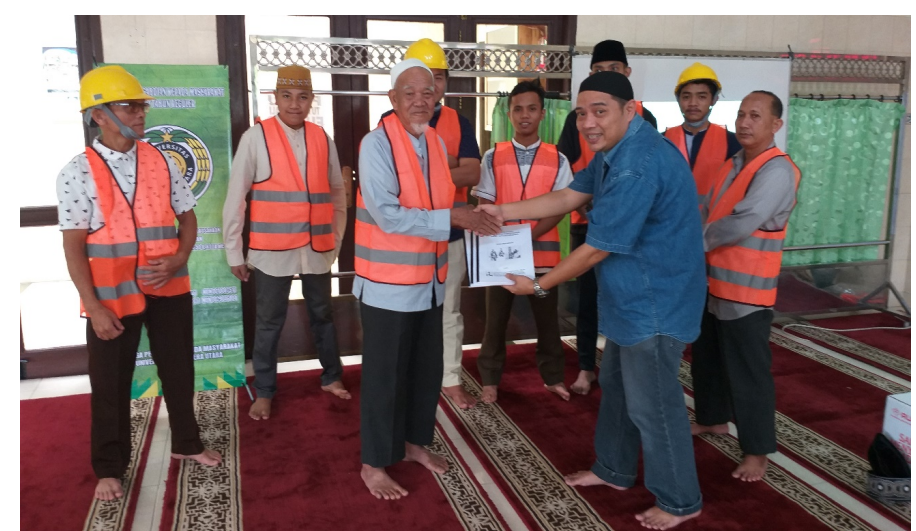

Gambar 3.4. Penyerahan modul pelatihan kepada Penasehat BKM sebagai mitra 


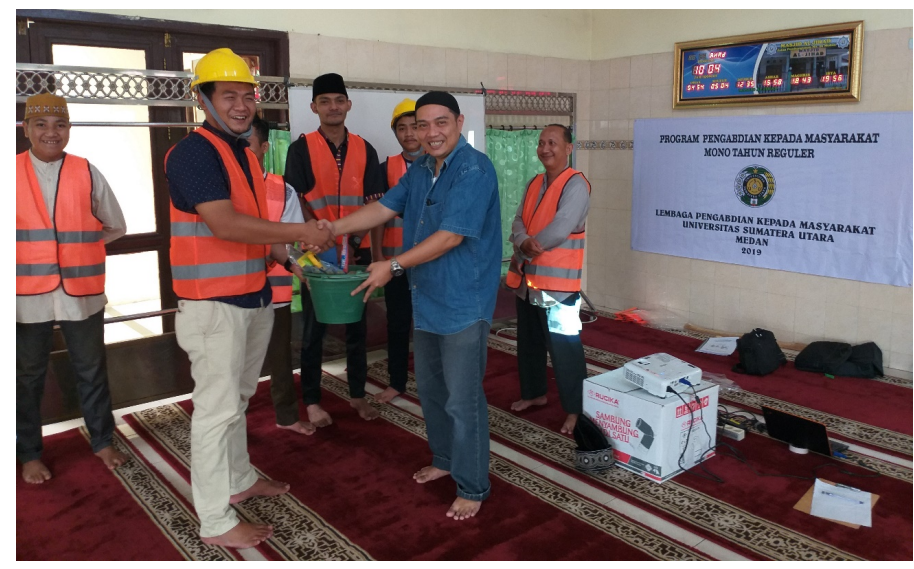

Gambar 3.5. Penyerahan peralatan kepada anggota BKM sebagai mitra

\section{KESIMPULAN}

Wujud kegiatan ini merupakan kemitraan bekerja sama dalam pelatihan ketrampilan terhadap permasalahan yang ditemukan pada mitra Masjid Al Jihad, yaitu adanya peningkatan jumlah kegiatan ibadah rutin berjamaah dan berkurangnya mutu layanan sarana ibadah memaksa pihak BKM Masjid dan masyarakat sekitar untuk melakukan renovasi pembangunan secara swakelola/mandiri dalam mengantisipasi masalah kegiatan ibadah islami diatas. Dalam pelaksanaan renovasi tersebut terdapat masalah rendahnya pengetahuan dan keterampilan SDM BKM dan masyarakat tentang teknik renovasi bangunan, yang ditandai dengan tingkat pendidikan tertinggi setara SMU. Menjadi solusi permasalahan tersebut diatas, untuk melakukan kegiatan pemahaman gambar, kontrol biaya bangunan serta simulasi konstruksi batu dan kayu dalam sebuah praktek mikro dalam renovasi bangunan. Kontribusi mendasar pada khalayak sasaran, yaitu adanya peningkatan keterampilan teknik renovasi bangunan sebagai langkah awal dari renovasi masjid mandiri oleh BKM dalam peningkatan mutu layanan sarana ibadah, serta peningkatan kualitas masyarakat dengan pengembangan karakteristik kewirausahaan di bidang jasa atau teknik renovasi bangunan.

Perlunya dilakukan pemantauan dan pendampingan dalam peningkatan keterampilan teknik renovasi bangunan selanjutnya dalam proses pelaksanaan fisik renovasi masjid mandiri oleh BKM mitra dalam peningkatan mutu layanan sarana ibadah, serta peningkatan kualitas masyarakat dengan pengembangan karakteristik kewirausahaan di bidang jasa atau teknik renovasi bangunan.

\section{UCAPAN TERIMAKASIH}

Tim Pengabdi mengucapkan terima kasih kepada Lembaga Pengabdian Pada Masyarakat (LPPM) Universitas Sumatera Utara yang telah Memberikan dana dengan skema mono tahun 2019, Nomor : 327/UN5.2.3.2.1/PPM/2019, Tanggal 20 Mei 2019. Ucapan terima kasih juga disampaikan kepada mitra, BKM Masjid Al Jihad, Siti Rejo II, Medan dalam terlaksananya kegiatan ini.

\section{DAFTAR PUSTAKA}

Albornoz, C. A. (2008). Toward A Set of Trainable Content on Entrepreneurship Education: $A$ Review of Entrepreneurship Research From Educational Prespective. J. Technol. Manag. Innov. 2008. Volume 3, Special Issue 1: 86-98. 
Devin dkk. Improvement of entrepreneurship

(www.jotmi.org/index.php/GT/article/viewFile/rev5/131-)

Arief, Zainal A. (2006), "Model Pembelajaran Kewirausahaan Berbasis Pada Konsep Academic Business Community “, (www.isjd.pdii.lipi.go.id/admin/jurnal/1610642.56/pdf)

Kellet, S. (2006). A Picture of Creative Entrepreneurship: Visual Narrative in Creative Entreprise Education. (online) (http://www.ncge.com/files/biblio 1002.pdf)

Kolb, A.D. \& Boyatzis, R.E. (1999). Experiential Learning Theory, Previous Research and New Direction. Case Western Reserve University.

Zimmerer, W. Thomas dan Norman M Scharborough (2008). "Kewirausahaan dan Manajemen Usaha Kecil'“, Jakarta : Penerbit Salemba Empat 